DOI: $10.19195 / 0137-1134.104 .6$

\title{
MARZENA KORDELA
}

Uniwersytet im. A. Mickiewicza w Poznaniu

\section{SYSTEMOWOŚĆ AKSJOLOGICZNA PRAWA}

Bez przesądzania o tym, jaki status ma wypowiedź o systemowości prawa założenie, zdanie empiryczne, postulat, warunek konieczny współczesnej refleksji nad prawem, bez którego zostałoby zanegowane przyjmowane w naszym kręgu kulturowym pojęcie prawa - jej akceptacja pociąga za sobą konieczność przyjęcia określonych konsekwencji, i to zarówno w wymiarze formalnym, jak i materialnym. Rozważania dotyczące prawa jako systemu nieodmiennie przypisują mu kwalifikację zbioru takich elementów, jakie mają charakter norm postępowania lub do nich są redukowalne. Nie ma definicji prawa - czy też systemu prawa — która jako jego właściwe elementy wskazywałaby wartości. Wartości, nie stanowiąc elementów systemu prawa w logicznym sensie tego słowa, są jednak jego niewątpliwymi składnikami — wyrażanymi w normach albo wprost (Konstytucje Hiszpanii i Chorwacji, zasady prawa ${ }^{1}$ ), albo pośrednio poprzez zachowania będące przedmiotem obowiązku, interpretowane jako przejaw określonych preferencji prawodawcy.

Doktryna prawnicza charakteryzuje relacje między prawem a wartościami poprzez użycie terminów wyraźnie przesądzających jedynie o pośrednim oddziaływaniu aksjologii na kształt obowiązujących norm prawnych. Stąd podkreślanie, że normy danego systemu prawnego znajdują uzasadnienie aksjologiczne (usprawiedliwi enie) w odpowiednio uporządkowanym systemie wartości, którym realizacja norm prawnych ma służyć [podkr. - M.K.] ${ }^{2}$

oraz sięganie po wyrażenia typu [wszystkie podkr. — M.K.]:

— wartości, jakim ma być podporządkowana konstytucja i oparty na niej system prawny ${ }^{3}$,

— przepisy nakazujące c hro n ić określone wartości ${ }^{4}$,

${ }^{1}$ M. Kordela, Zasady prawa jako normatywna postać wartości, „Ruch Prawniczy, Ekonomiczny i Socjologiczny" 2006, z. 1, s. 47.

2 Z. Ziembiński, Wartości konstytucyjne. Zarys problematyki, Warszawa 1993, s. 7.

3 Ibidem, s. 36.

4 Ibidem, s. 37, 42. 
— przepisy nakazujące ki erowanie się określonymi wartościami przy wyborze działań zmierzających do określonych celów ${ }^{5}$,

— deklarowanie uznania określonych wartości ${ }^{6}$,

— nakazy i zakazy d otyc zące wartości ${ }^{7}$,

— przepisy określające wartości konstytucyjne ${ }^{8}$,

— porządek wartości przyj mow any ch w danym systemie prawnym ${ }^{9}$,

— wartości ogólnie wskazywane w przepisach konstytucji ${ }^{10}$,

- uznawanie określonych wartości, którym system prawny ma służy ć ${ }^{11}$,

— wartości, które mają dawać podstawy aksjologiczne konstytucji i systemu norm prawnych na niej opartych ${ }^{12}$,

— wartości deklarowane czy zakładane przez ustawy konstytucyjne ${ }^{13}$.

Prawo nie tylko jednak chroni pewne wartości, jest uzasadniane nimi, czy też je zakłada, ale nadto wprowadza je wprost do swego porządku ${ }^{14}$. $Z$ uwagi na to, że porządek ten jest wyznaczony przez systemowość, również wartości zostają w ten sposób zorganizowane.

Spośród dwóch podstawowych właściwości systemu prawa — spójności oraz zupełności - w podstawowym wymiarze jedynie spójność odwołuje się do wartości prawodawcy, i to wyłącznie w wymiarze pozaformalnym, treściowym. $\mathrm{W}$ tym znaczeniu system prawny jest spójny aksjologicznie, jeżeli prawodawca jako racjonalny podmiot konsekwentnie preferuje określony stan rzeczy przed innym. Mimo dominacji ujęć akcentujących treściowe powiązanie wartości, wydaje się, że to właśnie ich wymiar formalny stanowi podstawowe spoiwo dla systemowości aksjologicznej prawa. Formalna perspektywa systemu wartości prawnych ujawnia się przede wszystkim w samym pojęciu wartości oraz systemu aksjologicznego; w charakterystyce cech przypisywanych systemowi wartości: spójności, zupełności, hierarchiczności, jego stabilności oraz zmienności; w kolizyjności wartości oraz procedurze ich wyważania.

W literaturze prawniczej niezmiernie rzadko pojawiają się próby definiowania terminu „wartość” czy choćby jego najbardziej ogólnego objaśnienia. Przyjmuje się z reguły, że istniejący uzus językowy - wsparty rozpowszechnionymi intuicjami - wystarczy do poprawnego operowania tym pojęciem. Jeżeli prowadzone wywody ograniczają się do twierdzeń aksjologicznych wywodzących się z tradycją

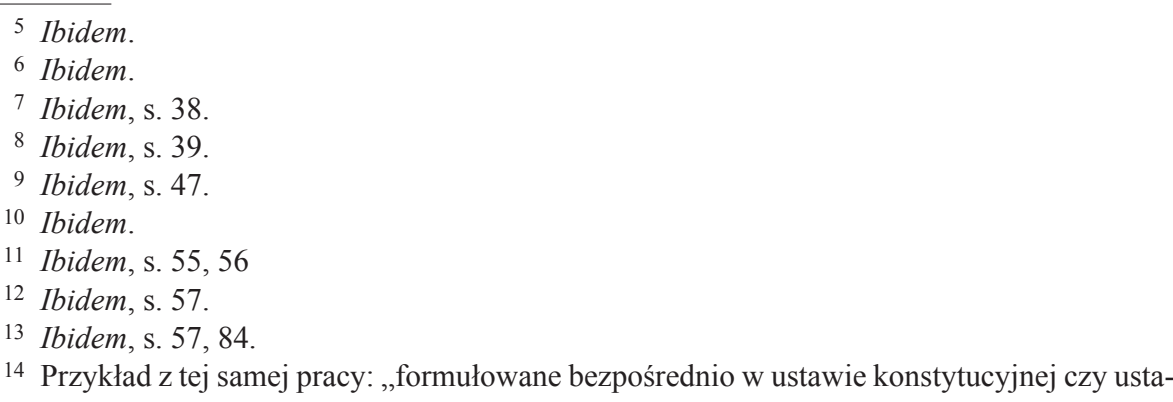
wach zwykłych nakazy realizowania [...] określonych wartości [podkr. - M.K.]" - ibidem, s. 9. 
ugruntowanego kanonu ${ }^{15}$, istnieje niewielkie prawdopodobieństwo, że pojawi się problem wymagający rozstrzygnięcia poprzez odwołanie się choćby do niektórych postulatów znaczeniowych terminu „wartość”. Współczesny etap ewolucji porządku prawnego - i to zarówno krajowego, jak i pozakrajowego — coraz częściej wymaga sięgania do samych korzeni myślenia o prawie. Radykalna nowość zagadnień wymagających reakcji prawnych oraz nieprzewidywalny kontekst kwestii kwalifikowanych tradycyjnie jako prawne nieuchronnie prowadzą do dokonywania wyborów aksjologicznych niemających wcześniejszych wzorców. W takich przypadkach intuicyjne znaczenie wartości okazuje się niewystarczające.

Można wyróżnić co najmniej cztery podstawowe sposoby użycia terminu „Wartość".

W pierwszym znaczeniu — uwidocznionym w zdaniu o schemacie „Wartością jest, że S jest P” — „wartość" syntaktycznie pełni funkcję orzecznika, zaś zdanie „S jest P" — podmiotu. Występując jako przymiotnik „,wartościowy”, słowo to morfologicznie ma taką samą postać jak przymiotniki typu „,czerwony”, „twardy” czy „szorstki”. Ale istnieje między nimi zasadnicza różnica. Gdy określeniu „,czerwony” odpowiadają treści przedstawień ${ }^{16}$, powodujące, że dwa wyrażenia — „To jest jabłko” oraz „To jest czerwone jabłko” — tworzą odmienne opisy danego obiektu, tego rodzaju relacja nie ma miejsca w odniesieniu do określenia „wartościowy”. Kwalifikacja jabłka jako wartościowego nie przydaje niczego do jego opisu. Nie przydaje, ponieważ określenie to przynależy do transcendentaliów, a więc jest nieprzedstawialne (podobnie jak przymiotniki typu ,istniejący”, „możliwy” czy „,konieczny”). Pewność, że dany przymiotnik zawiera się w klasie transcendentale, zyskuje się poprzez wykazanie, że można go stwierdzić w zdaniu modalnym typu: „Dobrze, że S jest P” lub „Pięknie, że S jest P”. Orzeczenia właściwe nie mają zdolności do budowy takich zdań (zdanie o kształcie „Czerwono, że...” jest nieskładne) ${ }^{17}$.

Transcendentalia jako nieprzedstawialne nie dotyczą jakiejkolwiek cechy. Jako przedmiot sądów przysługują jednak obiektom w postaci określeń stwierdzalnych poprzez zdania modalne. Tworząc kategorię sposobów bycia przedmiotów (modi entis), transcendentalia służą do przypisywania jakiejś cechy pewnemu obiektowi według jakiegoś modi. Czerwoność jabłka jest wartościowa (dobra) ${ }^{18}$.

W drugim znaczeniu - występującym w zdaniu o schemacie „ $X$ jest wartościowe (dobre, cenne, pozytywne)", gdzie symbol $X$ oznacza przedmiot indywi-

15 Przywołane sposoby odwoływania się do wartości w odniesieniu do prawa są jednocześnie klasycznymi składnikami tego kanonu. Zob. przypisy od 2 do 14.

$16,[\ldots]$ przedstawieniem nazywa się zjawisko psychiczne, w którym uobecniamy sobie przedmiot, to znaczy poznajemy, jakim on jest, nie stwierdzając ani nie zaprzeczając jego istnienia. Posiadam przedstawienie, gdy rozumiem, co znaczy »ptak«, »zieleń«, »liczba«". T. Czeżowski, Główne zasady nauk filozoficznych, Wrocław 1959, s. 9.

17 T. Czeżowski, Czym są wartości?, [w:] idem, Filozofia na rozdrożu (Analizy metodologiczne), Warszawa 1965, s. 120.

18 Ibidem. 
dualny - stwierdzenie bycia wartościowym odnosi się do kryterium wartościowania ${ }^{19}$. Jeżeli dane rozporządzenie jako akt wykonawczy do określonej ustawy jest ocenione jako dobre, bo legalne, to jego wartościowość powinna być interpretowana jako efekt spełnienia przyjętego wzorca legalnego aktu normatywnego.

Trzecie znaczenie terminu ,wartość” ujawnia się w następującej definicji: „W najprostszym psychologicznym rozumieniu wartością (dla kogoś) jest to, co jest przez dany podmiot trwale aprobowane [...]"20. Ten sposób objaśnienia wartości pozwala na przypisanie charakteru wartości każdemu stanowi rzeczy (procesowi, zdarzeniu, czynowi, rzeczy oraz wszystkim innym obiektom wystarczająco wyodrębnionym z rzeczywistości — zarówno faktycznej, jak i społecznej), jeżeli przyjęta wobec niego postawa oceniająca została dopełniona sformułowaniem stanowczej wypowiedzi oceniającej (pozytywnej, negatywnej albo indyferentnej). W tej perspektywie wartością może stać się wyrok, akt normatywny czy wykładnia prounijna.

Czwarty sposób użycia terminu „wartość” praktycznie nie występuje w naukach prawnych, ale wydaje się, że dla założenia systemowości aksjologicznej prawa ma znaczenie fundamentalne. W 1974 roku L. Nowak sformułował następującą definicję wartości: „Rodzina zbiorów równocennych stanów rzeczy należących do zbioru $W$ jest wartościq wtedy i tylko wtedy, gdy jest ona uporządkowana przez relację preferencji generalnej $P^{*}{ }^{21}$.

Spośród wskazanych pojęć wartości ${ }^{22}$ najczęściej zarówno w nauce prawa, jak i w orzecznictwie stosuje się ujęcie trzecie, ale i pozostałe - włącznie z ostatnim — występują w wielu kontekstach. Mimo że w każdym z tych czterech przypadków pojawia się słowo o tym samym kształcie, ale o odmiennym znaczeniu, niebezpieczeństwo błędu w rozpoznaniu właściwej konotacji wydaje się niewielkie, gdyż różnice są wyraźne.

Przyjęcie w prawoznawstwie założenia o racjonalności prawodawcy przesądza o tym, że wymóg racjonalności obejmuje także sferę aksjologii. Prawodawca jako racjonalny aksjolog nie tylko żywi określone wartości, ale nadto proces ich przyjmowania oraz porządkowania poddaje rygorom generalnie ujmowanej zasadzie racjonalności ${ }^{23}$. Zgodnie z tą zasadą: jeżeli $X$ uznaje wiedzę $W$, która jest (1) niesprzeczna i jest (2) systemem (tzn. zawiera swe konsekwencje logiczne) oraz $X$

19 R. Alexy, A Theory of Constitutional Rights, przeł. J. Rivers, Oxford 2002, s. 89-92; A. Peczenik, On Law and Reason, Berlin 2008, s. 61.

20 Z. Ziembiński, op. cit., s. 12.

21 L. Nowak, U podstaw marksistowskiej aksjologii, Warszawa 1974, s. 14.

22 Wskazane koncepcje wartości są wyborem z istniejącego katalogu. Por. na przykład ujęcie wartości z perspektywy socjologii prawa, w: K. Pałecki, Redukcja aksjologiczna jako sposób objaśniania porządku społecznego, [w:] Aksjologiczny wymiar prawa, red. R. Dudek, M. Stępień, Kraków 2015, s. 33-34.

${ }^{23}$ L. Nowak, Interpretacja prawnicza. Studium z metodologii prawoznawstwa, Warszawa 1973, s. 39; podobnie szczegółowe nauki o prawie, zob. na przykład P. Tuleja, Stosowanie Konstytucji RP w świetle zasady jej nadrzędności (wybrane problemy), Kraków 2003, s. 182. 
żywi preferencje, które są (3) asymetryczne i (4) przechodnie, to $X$ przyjmuje taką spośród możliwych (w świetle jego wiedzy) czynności, która niezawodnie prowadzi (wedle tej wiedzy) do najwyżej preferowanego stanu rzeczy ${ }^{24}$. Relacja ma postać asymetrycznej, gdy zachodząc między danym stanem rzeczy $R_{1}$ i stanem rzeczy $\mathrm{R}_{2}$, nie zachodzi między stanem rzeczy $\mathrm{R}_{2}$ a stanem rzeczy $\mathrm{R}_{1}{ }^{25}$. Natomiast relacja jest przechodnia, gdy jeżeli zachodzi między stanem rzeczy $R_{1}$ i $R_{2}$ oraz między $\mathrm{R}_{2} \mathrm{i} \mathrm{R}_{3}$, to także zachodzi między $\mathrm{R}_{1} \mathrm{i}_{3}{ }^{26}$. Złożenie obu relacji tworzy relację preferencji $P$.

Niebudzący wątpliwości akt preferowania przez prawodawcę stanu rzeczy $R_{1}$ przed stanem rzeczy $R_{2}$ wywołuje skutek o charakterze aksjologicznym: oba stany rzeczy stają się wartościami, a nadto podlegają hierarchicznemu uporządkowaniu. Ostatecznie więc to sam prawodawca decyduje o „wartościowości” jakiegoś obiektu (czynu, układu rzeczy, procesu etc.). Co więcej, owa decyzja z punktu widzenia jej istotowej charakterystyki odpowiada dokładnie decyzji normodawczej: podobnie jak normę postępowania akt stanowienia włącza w porządek prawny, tak akt preferowania ma charakter aktu stanowienia wartości prawnej. Przy czym aksjologiczne fiat prawodawcy może obejmować zarówno treść wartości, jak i jej prawne obowiązywanie (np. legalność, pewność prawa), ale także jedynie prawność wiązania, jeżeli wartość wcześniej ukształtowana merytorycznie w innych systemach aksjologicznych (moralnym, obyczajowym, estetycznym czy innym) zostanie włączona do zbioru wartości prawnych (np. prawda materialna, ład urbanistyczny, mir domowy).

Jeżeli więc prawodawca zajmuje wyraźne stanowisko w sferze żywionych przez siebie wartości, to do zadań interpretatora należy jedynie odpowiednie ich odkodowanie $^{27}$. Wartości prawne są bowiem dane (zawierają się w kategorii wartości ex post ${ }^{28}$ ), czynność egzegetyczna powinna więc mieć charakter czysto poznawczy. W tym ujęciu wyrażenie stwierdzające, że dany fragment tekstu prawnego stanowi podstawę do uzasadnienia wiązania określonej wartości, jest po prostu zdaniem w sensie logicznym, opisującym fakt przynależenia danej wartości do klasy wartości prawnych.

Aksjologia prawa w swej sferze metodologicznej wskazuje na zestaw narzędzi, przy użyciu których można dokonać skutecznej argumentacji na rzecz obowiązywania danej wartości jako prawnej.

Najbardziej jasny komunikat w tym porządku stanowi zakwalifikowanie wprost $\mathrm{w}$ akcie normatywnym wskazanej wartości jako prawnej. Wprawdzie ta technika nie jest stosowana przez polskiego prawodawcę, ale sięgnęli po nią na

${ }^{24}$ L. Nowak, Interpretacja..., s. 39.

25 Z. Ziembiński, Logika praktyczna, wyd. 26, Warszawa 2011, s. 97.

26 Ibidem, s. 98.

27 S. Kaźmierczyk, Z teoretycznoprawnej problematyki wykładni prawa, [w:] Lokalny a uniwersalny charakter interpretacji prawniczej, red. P. Kaczmarek, Wrocław 2009, s. 20.

${ }^{28}$ L. Nowak, U podstaw..., s. 110. 
przykład ustrojodawcy hiszpański i chorwacki ${ }^{29}$. Artykuł 1 Konstytucji Hiszpanii z 1978 roku w swoim pierwszym ustępie przesądza o tym, że: „Hiszpania konstytuuje się w postaci społecznego i demokratycznego państwa prawnego, które chroni jako najwyższe wartości swego porządku prawnego wolność, sprawiedliwość, równość i pluralizm polityczny"30, zaś Konstytucja Republiki Chorwacji z 1990 roku w artykule trzecim głosi, że: „Wolność, równość, równość narodów i równość płci, umiłowanie pokoju, sprawiedliwość społeczna, poszanowanie praw człowieka, nienaruszalność własności, poszanowanie natury i środowiska naturalnego, rządy prawa oraz demokratyczny system wielopartyjny stanowią najwyższe wartości porządku konstytucyjnego Republiki Chorwacji i podstawę wykładni Konstytucji" ${ }^{31}$.

Mimo braku wprowadzenia do polskiego języka prawnego wyrażenia ,wartość prawna", to ze względu na co pewnego typu stan rzeczy może być ujęty jako aprobowany przez prawodawcę, w wielu przypadkach objęte zostało zakresem opinio necessitatis doctorum. Przyjmuje się więc, że standardowym źródłem wiedzy o żywionych przez prawodawcę wartościach powinny być preambuły, przede wszystkim do konstytucji, ale także do ustaw konstytucyjnych i ustaw zwykłych. Wprawdzie ze względu na uroczysty charakter tych wstępów zdecydowanie dominują tak zwane „wartości wysokie” (w Konstytucji RP np. przyrodzona godność człowieka, prawa obywatelskie, wolność, sprawiedliwość), ale już sam fakt odwołania się do nich oraz podkreślenie ich wagi powoduje, że powstaje obowiązek prawny brania ich pod uwagę $\mathrm{w}$ procesach tworzenia, stosowania oraz interpretacji prawa $-\mathrm{z}$ co najmniej takim skutkiem, że wykazanie niezgodności z którąkolwiek z tych wartości pozbawia dane czynności (i ich efekty) znamienia poprawności. Preambuły także bardzo często formułują wprost cel swego aktu normatywnego. Kwalifikowana jako pożądany stan rzeczy ratio legis staje się tym samym wartością, tym jedynie różniąc się od innych wartości prawodawcy, że kształt jej realizacji zostaje przesądzony poprzez co najmniej ogólne wskazanie przyszłego rezultatu.

Wyrazem stanowiska aksjologicznego prawodawcy są także pewne kategorie normatywne, przede wszystkim zasady prawa, normy programowe oraz normy tworzące spójny kompleks zwany prawami i wolnościami człowieka.

Każda zasada jako obowiązująca norma prawna zyskuje taki status ze względu na doniosłą rolę, jaką pełni w systemie prawa ${ }^{32}$. Ta rola da się wylegitymować

29 Zob. też na przykład art. 2 Traktatu o Unii Europejskiej: „Unia opiera się na wartościach poszanowania godności osoby ludzkiej, demokracji, równości, państwa prawnego, jak również poszanowania praw człowieka, w tym praw osób należących do mniejszości. Wartości te są wspólne Państwom Członkowskim w społeczeństwie opartym na pluralizmie, niedyskryminacji, tolerancji, sprawiedliwości, solidarności oraz na równości kobiet i mężczyzn”.

30 Konstytucja Hiszpanii, przeł. T. Mołdawa, Warszawa 2008, s. 30.

31 Konstytucja Republiki Chorwacji, przeł. T.M. Wójcik, M. Petryńska, Warszawa 2007, s. 20.

32 M. Zieliński, Konstytucyjne zasady prawa, [w:] Charakter i struktura norm konstytucji, red. J. Trzciński, Warszawa 1997, s. 63. 
poprzez przyjęcie, że norma ma rangę zasadniczej ze względu na typ obowiązku, który kreuje - obowiązku realizacji określonej wartości ${ }^{33}$. Stąd nazwy występujące jako argumenty funktora nazwotwórczego ,zasada” — na przykład państwo prawne, sprawiedliwość społeczna, wolność gospodarcza, prawo do prywatności, nieretroakcja (i tworzące odpowiednie zasady: zasadę państwa prawnego, zasadę sprawiedliwości społecznej czy zasadę nieretroakcji) — to jednocześnie nazwy wartości, i to wartości tworzących zbiór nadrzędny w stosunku do pozostałych wartości prawnych, a nadto zawierających w swoim obrębie zbiór wartości naczelnych.

Normy programowe jako formułujące pod adresem organów władzy publicznej powinność prowadzenia określonej polityki — na przykład stwarzania warunków upowszechniania i równego dostępu do dóbr kultury (art. 6 ust. 1 Konstytucji RP), otaczania specjalną opieką weteranów walk o niepodległość (art. 19), zmierzającej do pełnego, produktywnego zatrudnienia (art. 65 ust. 5), zapewniającej bezpieczeństwo ekologiczne współczesnemu i przyszłym pokoleniom (art. 74 ust. 1), sprzyjającej zaspokojeniu potrzeb mieszkaniowych obywateli (art. 75 ust. 1) — przedmiot tej polityki czynią właściwym obiektem obowiązku. Obowiązek ten ma wyraźny charakter instrumentalny w stosunku do cenionego już samoistnie stanu rzeczy: dostępu do dóbr kultury, dobrostanu weteranów walk o niepodległość, pełnego zatrudnienia, bezpieczeństwa ekologicznego, zaspokojenia potrzeb mieszkaniowych obywateli. W odróżnieniu od zasad prawa normy programowe nie nakazują więc bezpośredniego realizowania autonomicznych wartości prawnych (jakkolwiek je niewątpliwie wyodrębniają), ale stanowią podstawę dla prawnego wymogu podjęcia całego kompleksu działań i to rozłożonych w czasie (przy czym natura większości wartości-celów przesądza praktycznie o konieczności trwałej obecności owych działań) po to, aby powstało otoczenie „sprzyjające”, „zmierzające do” czy „stwarzające warunki” dla realizacji wartości właściwych. To, jaką ostatecznie postać przyjmą formy spełnienia wartości instrumentalnych, zależy zawsze zarówno od czasu, jak i obowiązującego prawa.

Samodzielność aksjologiczna regulacji praw i wolności jednostki — co najmniej w sferze praw fundamentalnych - ma już swoje trwałe miejsce w definiowaniu systemu wartości prawodawcy ${ }^{34}$. Godność człowieka jako wartość centralna dla przyjmowanego katalogu praw staje się tym samym naczelną wartością prawną, a w pewnej perspektywie - wartością najwyższą. Gromadzone wokół niej wartości — zarówno ze sfery praw i wolności osobistych oraz politycznych, jak i ze sfery praw ekonomicznych, socjalnych i kulturalnych — traktowane są jako konieczne dla realizacji podstawowego celu: zagwarantowania poprzez prawo wszechstronnego rozwoju osobowości jednostki. Przenikając cały system

33 M. Kordela, Zasady prawa. Studium teoretycznoprawne, Poznań 2012, s. 102.

$34,[\ldots]$ prawa i wolności obywatelskie służą prawnej proklamacji ochrony wartości, które ważne są dla losów jednostki i współżycia w ramach społeczeństwa” w: Z. Kędzia, Konstytucyjna koncepcja praw, wolności, obowiązków człowieka i obywatela, [w:] Prawa, wolności i obowiązki człowieka i obywatela w nowej polskiej konstytucji, red. Z. Kędzia, Poznań 1990, s. 23. 
prawny poprzez swój konstytucyjny status, tworzą tym samym ramy aksjologiczne dla wszystkich aktów tworzenia i stosowania prawa.

Wyodrębnianie aspektu aksjologicznego w prawie zazwyczaj wiąże się z przywoływaniem tak zwanych wartości wysokich. Sprawiedliwość, dobro wspólne, suwerenność narodu, pluralizm polityczny i wiele innych — pojawiają się w kontekście legitymizacji oraz badania poprawności wykładni i stosowania prawa. Jednakże do zbioru obowiązujących wartości prawnych należą także wartości z niższych poziomów, aż do poziomu najniższego, gdzie znajdują się wartości dnia codziennego. Przejście przez jezdnię na zielonym świetle należy kwalifikować jako pozytywny prawnie stan rzeczy, zaś zakłócanie ciszy nocnej - jako stan negatywny. Zakładając bowiem aksjologiczną racjonalność prawodawcy, należy przyjąć, że każdy przedmiot jego bezpośredniego bądź pośredniego nakazu ma charakter wartości dodatniej ${ }^{35}$, zaś każdy przedmiot zakazu — wartości ujemnej. Niewystępowanie terminologii aksjologicznej w tej sferze wiąże się przede wszystkim z funkcją prawa jako narzędzia do kierowania ludzkim postępowaniem. Jeżeli postępowanie zostaje określone wprost (nie ma wątpliwości co do tego, jaki czyn ma być wykonany), narzędzie staje się kompletne i nie wymaga jakiegokolwiek uzupełnienia, na przykład poprzez sięganie do aksjologii prawa. To, że samo to zachowanie ma status wartości prawnej, z punktu widzenia skuteczności prawa ma znaczenie wtórne.

System aksjologiczny prawodawcy obejmuje nie tylko zbiór wartości prawnych (wartości obowiązujących prawnie). Należą doń co najmniej dwa dalsze podzbiory: wartości, do których prawodawca odsyła, czyniąc je obiektem obowiązku zastosowania na przykład pod postacią klauzul generalnych I i II typu oraz te wartości ${ }^{36}$, jakie prawodawca powołuje (albo zakłada) na poziomie podstawowych uzasadnień filozoficznych i ideologicznych całego porządku prawnego. Oba te zbiory tworzą dwa coraz dalsze pierścienie wokół zbioru-jądra, czyli wartości prawnych. Wartości obowiązujące prawnie są legitymowane obowiązującymi normami prawnymi, przy czym przedmiotem analiz interpretacyjnych zazwyczaj nie staje się kwestia, czy dana wartość rzeczywiście ma taki charakter, gdyż nie budzi to wątpliwości, ale to, jaką treść owa wartość niesie. Drugi pas wartości w systemie aksjologicznym prawodawcy tworzą przede wszystkim te wartości moralne powszechnie akceptowane przez społeczeństwo, które ujawniają głównie zasady współżycia społecznego i — poprzez wyraźną decyzję prawodawczą powinny być wzięte pod uwagę w decyzji stosowania prawa. Skrajna sfera aksjologii porządku prawnego zawiera wartości bezpośrednio zewnętrzne w stosunku do wartości „działających” w prawie i w aktach jego stosowania. Mieszczą się

35 Co najmniej w takim znaczeniu, że zajęcie stanowiska przez prawodawcę jest lepsze niż jego brak (prawo- oraz lewostronny kierunek ruchu mają indyferentną kwalifikację aksjologiczną, ale brak wskazania, który z nich obowiązuje wiąże się ze stanowczą oceną negatywną).

36 Zob. na przykład L. Leszczyński, Stosowanie generalnych klauzul odsyłających, Kraków 2001, s. 66 . 
one jednak wciąż w systemie wartości prawodawcy, w szczególności poprzez ich przywoływanie wprost, jak ma to miejsce w przypadku preambuły do Konstytucji RP, gdzie zostały powołane „wartości uniwersalne”37 (prawda, sprawiedliwość, dobro i piękno) oraz „ogólnoludzkie wartości”38. Mimo że wszystkie te zbiory mają wyraźnie ukształtowane granice, nie ma wątpliwości, że mogą i rzeczywiście wpływają na siebie. Oddziaływanie nie ma przy tym charakteru jednostronnego: zarówno wartości wyrażone w zasadach prawnych wpływają na doprecyzowanie klauzul odsyłających ${ }^{39}$, jak i same klauzule mogą przesądzić o kształcie zasady chronionej w indywidualnym rozstrzygnięciu ${ }^{40}$.

Wszystkie wartości obowiązujące prawnie — z uwagi na porządkującą je relację preferencji przesądzoną założeniem o racjonalności prawodawcy — tworzą zbiór o cechach systemu. Systemowość aksjologii prawnej ujawnia się w wielu perspektywach. Najczęstszym jej przejawem jest wyodrębnienie pewnej wartości - jednej albo niewielkiej ich grupy — i przyznanie jej miana naczelnej, co pociąga za sobą zakwalifikowanie wszystkich pozostałych do kategorii wartości zwykłych (a co najmniej nie-naczelnych). Współczesna polska doktryna prawnicza stosuje dwie techniki budowania takiego podziału dychotomicznego: albo wskazuje wprost taką wartość, albo określa ich kategorię. W pierwszym przypadku funkcję wartości naczelnej pełni albo państwo prawne, albo godność człowieka, przy czym ta druga sytuacja ma miejsce przede wszystkim wówczas, gdy odtwarzana jest aksjologia praw człowieka. Kategorialne ujęcie wartości naczelnych utożsamia je $\mathrm{z}$ wartościami konstytucyjnymi jako posiadającymi najwyższą moc prawną. Ta metodologia odkrywania systemowości aksjologicznej prawa zakłada, że podstawowe narzędzie porządkowania wartości prawnych stanowi gromadzenie wartości w mniejsze zbiory i umieszczanie owych zbiorów (a nie pojedynczych ich elementów) na odpowiednim szczeblu hierarchii aksjologicznej prawodawcy. Ten zabieg pozwala na wstępne, schematyczne, ale jednocześnie zupełne ujęcie wartości prawnych. Może się to odbywać na różne sposoby i w odniesieniu do różnych zakresów systemu prawa: od całego systemu prawa aż po jego najmniejsze fragmenty (instytucje a nawet poszczególne przepisy, przede wszystkim te wyrażające zasady prawa). Wartości konstytucyjne będą więc nadrzędne w stosunku do zbioru wartości ustawowych, a te z kolei do zbioru wartości podustawowych. Wartości prawa publicznego zostaną podporządkowane naczelnej wartości interesu społecznego (interesu publicznego, zbiorowego, powszechnego), z kolei wartości prawa prywatnego jako wartość naczelną przyjmą wartość interesu jednostki. Każda gałąź prawa posiada swoją aksjologię, a wartości naczelne są przesądzone poprzez wyraźnie formułowane zasady naczelne. Ale też poziom pojedynczych instytucji daje podstawę do budowy niewielkich, ale samodzielnych

37 Akapit piąty preambuły.

38 Akapit siódmy preambuly.

39 L. Leszczyński, op. cit., s. 116-121.

40 Ibidem, s. 121, 126. 
systemów wartości, gdzie na przykład instytucja własności opiera się na wyraźnie określonej wartości konstytucyjnej ochrony własności, a postępowanie dowodowe wartość prawdy materialnej czyni nadrzędną. Okazuje się więc, że systemowość aksjologiczna prawa jest wbudowana w samą jego istotę i ujawnia się nie tylko w perspektywie prawa ujmowanego jako jedna całość, ale konsekwentnie odtwarza się w każdej, nawet najmniejszej jego części, jeżeli tylko owa część stanowi określony - strukturalnie, treściowo, funkcjonalnie etc. - samodzielny byt.

Metodologiczną podstawę dla tworzenia hierarchii zbiorów wartości prawnych stanowi koncepcja L. Nowaka odwołująca się do pojęcia relacji preferowania generalnego. Oznaczona symbolicznie jako $P^{*}$ przyjmuje następującą postać definicyjną: „Z P*Z' wtedy i tylko wtedy, gdy dla każdego $p$ ze zbioru $Z$, dla każdego $q$ ze zbioru $Z^{\prime}: p P q$ " 41 . Symbole $Z$ oraz $Z^{\prime}$ odnoszą się do zbiorów równocennych stanów rzeczy, symbole $p$ oraz $q$ - do stanów rzeczy - elementów odpowiednich zbiorów. Relacja preferowania generalnego jest zarówno asymetryczna (jeżeli $Z P^{*} Z^{\prime}$, to nieprawda, że $Z^{\prime} P^{*} Z$ ), jak i przechodnia (jeżeli $Z P^{*} Z^{\prime}$ i $Z^{\prime} P^{*} Z^{\prime \prime}$, to $Z P^{*} Z^{\prime \prime}$ ) oraz spójna $\left(Z P^{*} Z^{\prime}\right.$ lub $\left.Z^{\prime} P^{*} Z\right)$. W powyższym ujęciu zbiór wartości konstytucyjnych jest preferowany generalnie w stosunku do zbioru wartości ustawowych, zaś zbiór wartości ustawowych jest preferowany generalnie w stosunku do zbioru wartości podustawowych. Relacja preferowania generalnego stanowi istotę przywoływanej wcześniej definicji wartości L. Nowaka.

Jeżeli więc wszystkie wartości prawne zostaną zgrupowane w zbiorach elementów o takiej samej cenności, to zbiory te będzie można uporządkować zgodnie z definicją preferowania generalnego — od zbioru najwyżej do najmniej preferowanego. Pomiędzy tymi zbiorami znajdzie się zbiór stanów rzeczy neutralnych aksjologicznie. Wszystkie stany rzeczy dominujące — ze względu na $P^{*}$ — nad neutralnymi stanami rzeczy będą miały charakter pozytywny aksjologicznie, zaś stany rzeczy, nad którymi dominować będą stany rzeczy aksjologicznie neutralne - charakter negatywny aksjologicznie ${ }^{42}$.

Cechą empirycznie stwierdzalną każdego dostatecznie rozwiniętego systemu aksjologicznego - a do tej kategorii należy system wartości prawnych — jest kolizyjność jego elementów. Polega ona na tym, że odpowiednio wysoki stopień realizacji danej wartości pozytywnej (i to praktycznie każdej wartości) nieuchronnie prowadzi do ograniczenia, a nawet wykluczenia realizacji innej wartości pozytywnej: maksymalna realizacja wolności słowa powoduje naruszenie prawa do prywatności, swobody gospodarczej — ograniczenie bezpieczeństwa ekologicznego, precyzji tekstu aktu normatywnego - zmniejszenie jego komunikatywności ${ }^{43}$. Prawodawca, świadom tej charakterystyki, w wielu przypadkach sam podejmuje

${ }^{41}$ L. Nowak, U podstaw..., s. 14.

42 Ibidem, s. 15.

43 Zob. np. stanowisko Cz. Znamierowskiego dotyczące dążeń zmierzających do realizacji niezgodnych wartości: „Każde z osobna chce pełnego zaspokojenia i protestuje przeciwko temu, że z kompromisu ma wyjść z niepełnymi rękami” w: idem, Oceny i normy, Warszawa 1957, s. 287. 
rozstrzygnięcie, mające na celu uzgodnienie opozycyjnych wartości, na przykład poprzez wyraźne sformułowanie zakazów wkraczania w pewne sfery (niedopuszczalność ograniczania własności w sposób podważający istotę tego prawa podmiotowego, definiowanie pewnych czynów jako przestępnych [zniesławienie, powodowanie zniszczenia $\mathrm{w}$ świecie roślinnym lub zwierzęcym $\mathrm{w}$ znacznych rozmiarach]). Nie wszystkie kolizje dadzą się jednak znieść w sposób generalny, gdyż, po pierwsze, prawodawca żywi wiele relacji preferencji i w chwili stanowienia prawa nie zawsze dysponuje należytą wiedzą co do tego, która $\mathrm{z}$ nich powinna być wzięta pod uwagę w akcie jego stosowania, często bardzo odległym od swego wejścia w życie, po drugie, nieprzewidywalność sytuacji, w jakich nastąpi kolizja, powoduje, że większe prawdopodobieństwo prawidłowości jej zniesienia wystąpi wtedy, gdy decyzję będzie podejmował podmiot stosujący prawo, w szczególności sąd, a nie sam prawodawca. Trzecie, i najbardziej istotne, uzasadnienie dla przyznania sądom wyraźnych kompetencji do wyważania wartości stanowi fakt, że wiele kolizji ujawnia się dopiero w porządku aplikacji prawa, a nie jego tworzenia.

Co niezmiernie charakterystyczne, procedura balansowania wartości w unikalnym akcie stosowania prawa - mimo że indywidualna i konkretna — także podlega regułom systemowości. Pierwszym krokiem jest zgromadzenie przez sąd wszystkich wartości ważnych ${ }^{44}$ (w ujęciu L. Nowaka) dla rozstrzyganego przypadku. Następnie należy sformułować kryteria dominacji jednej wartości nad drugą, przy czym czynność ta ma charakter w przeważającej mierze odtwórczy, gdyż kryteria owe muszą mieć legitymację w obowiązującym prawie (np. dominacja wartości prawdy materialnej nad innymi wartościami postępowania dowodowego, dominacja wartości ochronnych nad wartością winy w sytuacji, gdy sprawca czynu zabronionego sam wprawił się w stan odurzenia). Zbiór wartości relewantnych obejmuje następujące elementy: $V_{1}, V_{2}, \ldots, V_{n}, S_{k}, S_{k-1}, \ldots, S_{2}$, $S_{1}$. Pierwsza grupa wartości $-V_{l}, V_{2}, \ldots, V_{n}-$ to wartości równocenne (wartości ,jednakowo dominujące" ${ }^{45}$ ). Druga zaś $-S_{k}, S_{k-1}, \ldots, S_{2}, S_{1}$ - jest ściśle podporządkowana pierwszej: każda wartość ze zbioru $V$ dominuje nad każdą wartością ze zbioru $S$. Wszystkie składniki zbioru $S$ są uporządkowane ściśle preferencyjnie, co oznacza, że $S_{k}$ dominuje nad $S_{k-1}, S_{k-1}$ dominuje nad $S_{k-2}$ - aż do $S_{2}$ dominującego nad $S_{1}$.

Ze względu na immanentną kolizyjność wartości w praktyce niemożliwe jest zrealizowanie wszystkich wartości relewantnych. Stąd podmiot stosujący prawo musi podjąć decyzję co do tego, które ze zgromadzonych wartości uznać za nieistotne dla badanego przypadku. Podejmuje więc czynność abstrahowania od wartości najsłabszych, czynność racjonalnie uzasadnioną przyjętym uprzednio porządkiem wartości. Każdy podejmowany krok na tej drodze ma charakter autonomiczny i może dotyczyć tylko jednej — najniższej — wartości. Stąd kolejno

${ }^{44}$ L. Nowak, U podstaw..., s. 21-22.

45 Ibidem, s. 23. 
powstają zbiory wartości objęte obowiązkiem ich rozważenia w badanej sprawie: najpierw zbiór typu $V_{1}, V_{2}, \ldots, V_{n}, S_{k}, S_{k-1}, \ldots, S_{2}$ (po uznaniu $S_{1}$ za wartość nieistotną), następnie zbiór $V_{1}, V_{2}, \ldots, V_{n}, S_{k}, S_{k-1}, \ldots, S_{3}$ (gdy $S_{2}$ zostanie uznana za nieistotną) - aż po zbiór, który w ogóle nie będzie obejmował wartości rodzaju $S$. Zbiór ostateczny zawiera wyłącznie wartości najbardziej dominujące $V_{1}, V_{2}, \ldots, V_{n}^{46}$.

Powyższą procedurę można przedstawić pod postacią struktury aksjologicznej ${ }^{47}$ :

(k) $V_{1}, V_{2}, \ldots, V_{n}$

$(k-1) V_{1}, V_{2}, \ldots, V_{n}, S_{k}$

(1) $V_{1}, V_{2}, \ldots, V_{n}, S_{k}, S_{k-1}, \ldots, S_{2}$

(0) $V_{1}, V_{2}, \ldots, V_{n}, S_{k}, S_{k-1}, \ldots, S_{2}, S_{1}$

Cała struktura aksjologiczna składa się z tak zwanych poziomów dominacji, przy czym poziomem zerowym (powierzchniowym poziomem dominacji) jest ten, który obejmuje wszystkie wartości prawodawcy określone jako ważne dla danego przypadku. Każdy następny poziom odpowiada konkretnemu aktowi abstrahowania od kolejnej wartości ubocznej. Ostatni — najwyższy — poziom $k$-ty (wewnętrzny poziom dominacji) zawiera jedynie wartości główne.

Jeżeli zbiór wartości równorzędnych posiada więcej niż jeden element, to zazwyczaj podmiot stosujący prawo sięga po reguły superpozycji („składania”) wartości, przy czym nieodmiennie podstawy dla ich formułowania musi odnaleźć w wiążących decyzjach prawodawczych. Czynność „składania” wartości ma następującą postać ${ }^{48}: T=\pi\left(T_{1}, T_{2}, \ldots, T_{n}\right)$, gdzie symbol $\pi$ oznacza funkcję określoną na zbiorze równorzędnych wartości obowiązujących prawnie: $T_{1}, T_{2}, \ldots, T_{n}$, zaś $T$ to złożenie wartości $T_{1}, T_{2}, \ldots, T_{n}$.

Po zastosowaniu reguł superpozycji struktura aksjologiczna przybiera określoną formę:

(k) $V$

$(k-1) V, S_{k}$

(1) $V, S_{k}, \ldots, S_{2}$

(0) $V, S_{k}, \ldots, S_{2}, S_{1}$

${ }^{46}$ L. Nowak kwalifikuje wartości typu $V_{1}, V_{2}, \ldots, V_{n}$ jako wartości główne dla wszystkich przypadków rodzaju $K$, do których to przypadków należy przypadek badany, zaś wartości typu $S_{k}$ $S_{k-1}, \ldots, S_{2}, S_{1}$ jako wartości uboczne, ibidem, s. 22.

47 Ibidem.

48 Ibidem, s. 23. 
Budowane (a ściślej mówiąc — odtwarzane) przez L. Nowaka struktury aksjologiczne występują w każdym akcie stosowania prawa, w którym należy brać pod uwagę ważne dla danego badanego przypadku wartości. Ze względu na ograniczoną ilość tych wartości oraz na ustalony orzeczniczo i niekontrowersyjny sposób ich harmonizowania struktury aksjologiczne nie są wprost przywoływane. Ich rola jednak zmienia się w sytuacji, gdy pojawia się większy niż standardowy zbiór wartości relewantnych. Ma to miejsce przede wszystkim w orzecznictwie sądów najwyższych instancji - Sądu Najwyższego, Naczelnego Sądu Administracyjnego, a w szczególności Trybunału Konstytucyjnego, przy czym pojawia się — obok mnogości wartości — jeszcze jeden istotny czynnik: rozważane wartości należą najczęściej do wartości naczelnych polskiego prawodawcy (głównie konstytucyjnych) i nadto jeszcze pełnią wyraźnie samodzielną — obok norm — funkcję. Stąd też umieszczenie ich w określonym schemacie wyznaczającym każdej z nich wyraźną pozycję — także w odniesieniu do pozostałych wartości buduje podstawę dla ich racjonalnego wyważania.

Poprawność formalna przeprowadzenia procedury oceniania rozstrzyganego przypadku wymaga spełnienia dwóch warunków: wzięcia pod uwagę wartości głównych (wszystkich wartości typu $V$ ) oraz dokonania ich korekty przy zastosowaniu wartości ubocznych (wartości typu $S$ ) ${ }^{49}$. Ze względu na fakt, że praktycznie każdy analizowany stan sprawy ma charakter unikalny, sposób formułowania ostatecznej oceny nie tylko może, ale wręcz powinien się różnić. Struktury aksjologiczne pozwalają uchwycić tę zmienność poprzez to, że dla każdego przypadku — z uwagi na wielość preferencji żywionych przez prawodawcę - można zbudować nie jedną, ale więcej dopuszczalnych struktur. Wyznaczając w ten sposób swoisty ,pas nieostrości” 50 dla oceny sądu (to sąd będzie dokonywał wyboru, która z możliwych prawnie struktur stanie się uzasadnieniem dla decyzji aksjologicznej), jednocześnie buduje pewność co do tego, jakie struktury aksjologiczne są wykluczone. Ta negatywna przewidywalność w działaniach podmiotów stosujących prawo w porządku aksjologicznym stanowi największy przymiot koncepcji L. Nowaka struktur aksjologicznych. Uzupełnia ją przewidywalność pozytywna w sferze samych wartości. To, jaka wartość zostanie przez sąd zakwalifikowana jako prawna i tym samym stanie się choćby potencjalnym przedmiotem konkretnego badania, pozostaje poza sferą decyzyjną sądu. Tylko prawodawca jest władny przyznać wartości status prawnej i uczynić ją obowiązującą, zaś podmiot stosujący prawo jedynie tę wartość odtwarza ${ }^{51}$.

Założenie systemowości aksjologicznej prawa nie tylko determinuje więc sposób jego tworzenia, ale nadto wpływa na jego stosowanie. Szczególnego podkreślenia wymaga fakt, że dopiero na etapie stosowania prawa proces uspójnia-

49 Ibidem, s. 46.

50 Ibidem, s. 43.

51 Zob. np. P. Tuleja, op. cit., s. 64, 68, 74, 83, 137, 156, 190, 253, 292. 
nia porządku prawnego domyka się ostatecznie ${ }^{52}$. Dzieje się tak dlatego, że immanentna kolizyjność wartości powoduje, że ich ujęcie w normach generalnych i abstrakcyjnych pozostawia sądowi swobodę w decydowaniu co do wzajemnych granic realizacji opozycyjnych wartości ${ }^{53}$. Dopiero dana decyzja formułowania normy indywidualnej i konkretnej — prawidłowo albo nieprawidłowo - wykreuje całość normatywną (dana norma indywidualna i konkretna oraz wzięte pod uwagę normy generalne i abstrakcyjne), która powinna mieć przymiot bycia systemem. Toteż okazuje się, że co najmniej w pewnym zakresie zapewnienie spójności aksjologicznej prawa (jako najważniejszego składnika systemowości), czy też szerzej - porządku prawnego, należy do obowiązków zarówno samego prawodawcy, jak i podmiotów stosujących prawo ${ }^{54}$.

\section{AXIOLOGICAL COHERENCE OF LAW}

\section{Summary}

Law, qualified as a system, is characterized as such not only due to formal and content relations but also due to axiological relations. The assumption of legislator's rationality predetermines that by establishing legal norms the legislator is guided by a cohesive, hierarchical and relatively stable system of values (axiological rationality). By introducing a given value into a system of law the legislator makes it a value in legal force with all the consequences, e.g. one that regulations of a inferior legal force may not be in disagreement with it. Legal values themselves constitute a system and this coherence is recreated in narrower areas, as e.g. in branches (hence value systems in criminal law or in civil law).

52 A. Korybski, L. Leszczyński, Stanowienie i stosowanie prawa. Elementy teorii, Warszawa 2015, s. 152.

53 P. Tuleja, op. cit., s. 65, 89.

54 Zob. np. Z. Pulka, Legitymizacja państwa w prawoznawstwie, Wrocław 1996, s. 172. 